\title{
The Influence of Short-Term Insurance Industry on the Finance-Growth Nexus in South Africa
}

\author{
Mabutho Sibanda \\ School of Accounting, Economics and Finance, University of KwaZulu-Natal, \\ Private Bag X54001, Durban, 4000, South Africa; \\ Email: Sibandam@ukzn.ac.za; Tel: +27 31260 2160; \\ Merle Holden \\ School of Accounting, Economics and Finance, University of KwaZulu-Natal, \\ Private Bag X54001, Durban, 4000, South Africa
}

\section{Doi:10.5901/mjss.2014.v5n1p489}

Abstract

This study seeks to establish the influence of the short-term insurance industry on financial and economic development in South Africa. The study uses quarterly data from 1994 to 2009 to perform the Johansen (1991) co-integration tests and subsequently the Granger causality tests to establish the relationship between the short-term insurance industry and the finance-growth nexus. The study is premised on the 'demand-following' and 'supply-leading' propositions by Patrick (1966). Results show that the insurance industry has a positive relationship with economic development. The development of the short-insurance industry heavily relies on economic development rather than on banking sector development and financial deepness. This suggests that formulating policies that promote economic growth directly leads to the development of the shortterm insurance industry in South Africa confirming the demand-following proposition.

Keywords: short-term insurance, finance-growth nexus, Johansen, co-integration, institutional investors

\section{Introduction}

Despite ongoing research and debate on the finance-growth nexus worldwide, there is a paucity of studies on South Africa. Existing research shows that there is general consensus among economists that a developed financial system influences economic development and vice versa. This is the case even for resource-based economies like South Africa where banking sector development and stock market development positively impact on economic development. However, as finance seems to take a central role in most world economies, it is paramount to investigate the impact of institutional investors, in particular the short-term insurance industry, in driving this finance-growth nexus. The motivation to investigate this relationship emanates from the increasing gradual shift of financial resources from production of goods and services to finance, which diminishes resources available for the creation of physical assets in the economy. In South Africa finance contributes to just over 20 percent of the country's Gross Domestic Product (GDP). As finance becomes large in dollar terms, whether this implies less available physical capital is another matter. This recent and rapidly growing phenomenon has been termed 'financialization of capital'. While the role of resources as a key driver of both the financial markets and the economy is acknowledged, a snapshot of financial indicators shows that in South Africa, as in the United States of America and the United Kingdom, nonbank financial institutions are increasingly dominating the financial sector. Consequently, there exists a puzzle that entangles the theory of financial intermediation as founded by Joseph A. Schumpeter (1912), Solow-Swan (1956) and later by Patrick (1966), which forms the basis of neoclassic economics. Furthermore, the absence of a holistic approach to investigate the role that institutional investors, in particular short-term insurance firms, have in driving financial development and economic growth in South Africa renders the financial intermediation puzzle incomplete in respect of developing economies. This study therefore provides an empirical analysis of the influence of the short-term insurance industry on finance and the economy, which is fundamental to the debate on the 'finance-growth nexus' and financialization of capital in developing economies. 


\section{Aim of the Study}

This study seeks to establish the influence of short-term insurance firms on financial development and economic growth in South Africa. We summarize our objectives which are based on South African data spanning 1994 to 2009 as follows:

1. To ascertain the relationship between short-term insurance industry and financial development and economic development in South Africa.

2. To determine the relationship between short-term insurance and the finance-growth nexus through gross capital formation.

In this study financial development is split into three categories, namely: banking sector development, stock market development and financial deepening.

\section{Brief Review of Literature}

Non-deposit taking institutions have evolved over the past century to encompass a wide spectrum of financial service providers (Saunders and Connert, 2008). Definitions of these non-depository financial institutions point to their respective liability profiles. Insurance companies, according to Hull (2010) provide protection against adverse events. As such, insurance companies may be categorized into life and short-term insurance companies. Life insurance companies contract the payments to the policyholder and depend on when the policyholder dies. Thus life insurance firms have a long-term liability profile. Conversely, short-term insurance companies provide protection of assets against unanticipated and sudden events. Thus the liability profile of short-term insurance firms is of a short-term nature.

The role of institutional investors is increasingly becoming dominant in global financial markets, as their assets parallel those of the deposit-taking institutions (Committee on the Global Financial System, 2007). These institutional investors have been credited with financial innovation, which has since re-defined the financial intermediation structure and behavior (Davis, 2003). Other propositions on the role of non-bank financial institutions in both financial development and economic growth point to the lack of development of these non-bank financial institutions as hindering financial and economic development in most countries. For instance, work by Goldsmith (1969) shows that the financial structure tends to expand with economic development especially reflected by an increasing diversity of financial intermediaries. On the same note, Gurley and Shaw $(1955,1960,1973)$ posit that in the early stages of economic development, commercial banks tend to dominate the financial sector in terms of the share of total financial assets in the economy. However, this trend tends to decline with the mushrooming of other specialized financial intermediaries like pension funds, insurance companies, and mutual funds and as equity markets develop.

A recent study on the development impact of institutional investors on economic growth was conducted by Islam and Osman (2011). The study focused primarily on Malaysia. Using annual data spanning 20 years, the study employed the bounds testing approach to co-integration and error correction mechanism and found that institutional investors played a central role in both economic and financial development in Malaysia. Another study on the role of institutional investors in the development of the financial sector and economic growth in Organization for Economic Co-operation and Development (OECD) countries was conducted by Harichandra and Thangavelu (2004). The study incorporated the dynamic causality role of institutional investors in a Panel Vector Autoregressive framework based on a cross-sectional time series variability data of 23 OECD countries from 1988 to 1999. The study provided some striking evidence that showed a declining trend in the traditional activities of the banking sector in loans provision; thus development of institutional investors would gradually erode the traditional role of the banking sector.

Haiss and Sumegi (2006) also sought to establish the relationship between insurance and economic growth from both a theoretical and empirical view. The study was premised on 29 European countries over a 12-year period with an annual frequency and found mixed results across the countries. Like any other financial intermediaries, insurance firms perform the basic functions of transferring risk and mobilization of savings. However, in mobilizing savings in the economy, insurance firms become competitors to the deposit-taking banks with the former enabling clients to diversify his/her portfolio or substitute different investments (Haiss and Sumegi, 2005). This "substitution effect", according to the study, kicks into play from the fact that insurance firms insure losses; hence dependence on precautionary savings by companies and households is reduced. This occurs through premiums that companies and households pay to insurance companies, which imply withdrawal of savings from the banking industry to the insurance industry, which in turn invests in the financial markets.

Other empirical studies on the role of the insurance industry on economic development also found that insurance makes a positive contribution to economic development. For instance, a study by Holsboer (1999) revealed that 
increasing competition between the insurance industry and the banking industry was inevitable and found bidirectional causality between the insurance industry and economic development in Europe. Furthermore, the study found that the growth of the insurance industry further facilitates capital market development in Europe. Boon (2005) supports this proposition and shows that total insurance assets Granger cause GDP growth in the long run and capital formation in the short and long run. This relationship forms the basis of this study although the scope and methodology differ in that insurance-specific indicators like premiums are not considered in this study. Other studies include Outreville (1990) who conducted a cross-section analysis on insurance premiums, GDP, insurance price and other macroeconomic indicators in 55 developing countries and found that insurance premiums had a significant influence on financial development proxied by broad money supply (M2) to GDP ratio. Further, the Catalan et al (2000) study used Granger causality tests of insurance assets for 14 OECD countries on GDP growth and stock market capitalization to GDP ratio, and found unidirectional links from insurance assets to stock market development. Other studies that measured the relationship between insurance firms and macroeconomic and financial development variables used models ranging from Granger Causality to cross-sectional analyses and ordinary least squares (OLS) method. These include Ward and Zurbruegg (2000); Beck and Webb (2002); Park, Borde and Choi (2002); Lim and Haberman (2003) and Davis and Hu (2004). These studies focused on European and Asian countries using either insurance premiums or assets as proxies for the insurance industry.

\section{Research Design}

\subsection{Data and Description of Variables}

Table 1 shows the model variables and how they are measured in this study. The data used in the study are from the first quarter of 1994 to the fourth quarter of 2009.

Table 1: Description of Key Variables used in this study

\begin{tabular}{|l|l|l|}
\hline Variable & \multicolumn{1}{|c|}{ Description } & \multicolumn{1}{|c|}{ Data source } \\
\hline Percap & Log [Real GDP per capita (2005) in South African rands] & SARB Online Statistics \\
\hline M2 & Log [ Broad Money Supply (M2)/ GDP] & McGregor BFA Library database \\
\hline MC & Log [Market capitalization/GDP] & McGregor BFA Library database \\
\hline BCP & Log [Domestic Credit provided by banking sector/GDP] & SARB Online Statistics \\
\hline ST & $\begin{array}{l}\text { Log [Short-Term Insurance Companies Assets/ (Financial Assets of Institutional } \\
\text { Investors + Market capitalization + Domestic Credit provided by Banking } \\
\text { Sector)] }\end{array}$ & \\
\hline GCF & Log [Gross Capital formation/ GDP] & SARB Online Statistics \\
\hline
\end{tabular}

All the variables above are calculated in real terms (at 2005 constant prices) to eliminate the effects of inflation.

\subsubsection{Real per capita GDP (Percap)}

The study uses quarterly real per capita GDP data at 2005 constant prices to proxy economic development. Since the real per capita data is published on an annual basis, this study uses semi-annual population data published by Statistics South Africa to estimate quarterly population figures. Quarterly GDP values are then divided by quarterly population figures to obtain real per capita GDP series.

\subsubsection{Broad Money Supply to GDP ratio (M2)}

This variable is a proxy for financial deepness which is an arm of financial development.

\subsubsection{Stock Market Capitalization to GDP ratio (MC)}

This variable is a proxy for capital market development. Capital market development, like financial deepness is embodied in the measurement of financial development. 


\subsubsection{Domestic Bank Credit to Private Sector to GDP ratio (BCP)}

Bank credit to the private sector to GDP ratio is also a measure of financial development and also encapsulates the extent to which financial intermediaries channel savings to the real economy.

\subsubsection{Short-Term Insurance assets (ST)}

ST is a measure of the development of the short-term insurance industry.

\subsubsection{Gross fixed capital formation to GDP ratio (GCF)}

This variable captures other non-financial factors that drive economic development.

\subsection{Methodology}

The Vector Error Correction Model (VEC model) is employed to test the short-run and long-run relationships between short-term insurance assets and financial and economic development. In doing so, the Augmented Dickey-Fuller and Phillips and Perron tests for stationary and presence of unit roots in the series are performed prior to the Johansen (1991) co-integration tests.

The theoretical model employed in this study is shown in equation (1) below.

$G D P=f(B C P, S T, M 2, M C, G C F)$

where GDP is log real per capita GDP, BCP is log bank credit to private sector to real GDP ratio, ST is log shortterm insurance ratio, M2 is money supply to GDP ratio, MC is stock market capitalization to GDP ratio and GCF is log Gross Capital Formation to GDP ratio.

In conducting confirmatory data analysis, we establish whether each series is integrated of order I (0) or I (1). If the series is integrated of order I (0), then we use the vector autoregressive (VAR) model in levels. However, if the series is integrated of order $I(1)$, then co-integrating vectors may exist in the series and we proceed to use the VEC model as shown in equation (2) and (3) below. In using the model, the co-integrating rank (П) will show the number of cointegrating vectors. The VEC model may be written as:

$$
\Delta y_{t}=\mu+\Pi y_{t-1}+\sum_{i=1}^{p-1} \Gamma_{i}^{*} \Delta y_{t-i}+\varepsilon_{t}
$$

where $y_{t}$ denotes $m \times p$ vector of endogenous variables, $\mu$ is the $m \times 1$ vector of constants,

$\Pi=\sum_{\mathrm{j}=1}^{\mathrm{p}} \Gamma_{j}-1$ and $\Gamma_{i}^{*}=-\sum_{\mathrm{j}+1}^{\mathrm{p}}+\Gamma_{j}$

From the model $\Gamma_{i}^{*}$ explain the short-run dynamics, and $\Pi$ tell us about the co-integrating relations in the series. The rank of $\Pi$ may equal zero suggesting that no co-integration exists in the sequence at all in which all elements in the matrix $\Pi$ are zero. Also the rank of $\Pi$ could be full, (i.e. rank $=n$ ) implying that the series is stationary and can be modelled by VAR in levels. Finally, the rank of $\Pi$ can be reduced (i.e. $0<$ rank $<n$ ) implying that all variables are integrated of order $I(1)$ and the level based long-run component would be stationary suggesting that the appropriate methodology for the sequence is the VEC model. We use this model when the rank of $\Pi$ is reduced but greater than zero. The relationship is further illustrated in equation (4) below.

$$
\begin{aligned}
& \Delta Y_{t}=\alpha_{1}+p_{1} e_{1}+\sum_{i=0}^{n} \beta_{i} \Delta Y_{t-i}+\sum_{i=0}^{n} \delta_{i} \Delta X_{t-i}+\sum_{i=0}^{n} \gamma_{i} \Delta Z_{t-i} \\
& \Delta X_{t}=\alpha_{2}+p_{2} e_{i-1}+\sum_{i=0}^{n} \beta_{i} \Delta Y_{t-i}+\sum_{i=0}^{n} \delta_{i} \Delta X_{t-i}+\sum_{i=0}^{n} \gamma_{i} \Delta Z_{t-i}
\end{aligned}
$$

A negative and significant coefficient of the error correction model $\left(e_{i-1}\right)$ shows that any short-run fluctuations between the exogenous variables and the endogenous variable will lead to a stable long-run relation between the model variables (Asari et al., 2011). To test for causality, the study employs the VEC causality approach as shown in equation (4). In this equation, $Y$ will Granger cause $X$ if lagged values of $Y$ can be used to predict current and future values of $X$ better than just using lagged values of $X$.

\section{Results and Discussion}

Confirmatory data analysis is used to establish whether the series is stationary or contains unit roots. The Percap, BCP, MC, GCF, ST and M2 variables are established to be integrated of order I(1) (contain unit roots) and consequently, a test on short-term insurance assets shows that the series is integrated of order I(1) as the null hypothesis that the series 
contain a unit root at levels is not rejected. These results are confirmed by both confirmatory data analysis techniques employed in this study. The results are summarized in table 2 and 3 below.

Table 2: Augmented Dickey-Fuller test

\begin{tabular}{|l|l|l|l|l|l|}
\hline \multicolumn{2}{|c|}{} & \multicolumn{2}{|l|}{ Level, constant (no trend) } & \multicolumn{2}{l|}{ First difference, constant (no trend) } \\
\hline & & $\mathbf{t}$ statistic & Prob $^{*}$ & t statistic & Prob $^{*}$ \\
\hline Short-term Ins & -0.339447 & 0.9123 & -7.003627 & 0.0000 \\
\hline Percap & -0.110779 & 0.9432 & -3.581634 & 0.0089 \\
\hline M2 & -0.551525 & 0.8731 & -10.43920 & 0.0000 \\
\hline GCF & -0.124250 & 0.9414 & -2.954637 & 0.0454 \\
\hline MC & -0.993719 & 0.9414 & -6.983571 & 0.0000 \\
\hline BCP & -0.472480 & 0.8891 & $-8.69-4993$ & 0.0000 \\
\hline \multirow{3}{*}{ Test Critical Values } & $1 \%$ & -3.538362 & & -3.540198 & \\
\cline { 2 - 6 } & $5 \%$ & -2.908420 & & -2.909206 & \\
\cline { 2 - 6 } & $10 \%$ & -2.591799 & & -2.592215 & \\
\hline
\end{tabular}

* MacKinnon (1996) one-sided p-values

Table 3: Phillips-Perron test

\begin{tabular}{|c|c|c|c|c|c|}
\hline & \multicolumn{2}{|c|}{ Level, constant (no trend) } & \multicolumn{2}{|c|}{ First difference, constant (no trend) } \\
\hline & & t statistic & Prob* & t statistic & Prob* \\
\hline \multicolumn{2}{|c|}{ Short-term Ins } & -0.383254 & 0.9051 & -6.978214 & 0.0000 \\
\hline \multicolumn{2}{|l|}{ Percap } & -0.118552 & 0.9424 & -3.646098 & 0.0074 \\
\hline \multicolumn{2}{|l|}{ M2 } & -0.336930 & 0.9127 & -11.03843 & 0.0000 \\
\hline \multicolumn{2}{|l|}{ GCF } & -0.674090 & 0.8453 & -8.150112 & 0.0000 \\
\hline \multicolumn{2}{|l|}{$\mathrm{MC}$} & -2.178613 & 0.2160 & -6.983571 & 0.0000 \\
\hline \multicolumn{2}{|l|}{$\mathrm{BCP}$} & -0.461925 & 0.8911 & -8.664143 & 0.0000 \\
\hline \multirow{3}{*}{ Test Critical Values } & $1 \%$ & -3.538362 & & -3.540198 & \\
\hline & $5 \%$ & -2.908420 & & -2.909206 & \\
\hline & $10 \% 1$ & -2.591799 & & -2.592215 & \\
\hline
\end{tabular}

* MacKinnon (1996) one-sided p-values

Since the two confirmatory data analysis techniques show that the series is integrated of order $I$ (1), then a test for cointegrating relations in the series based on Johansen (1991) methodology is performed. The number of co-integrating equations is found using the Trace Tests and the Maximum-Eigenvalues (Johansen and Juselius, 1990), and is shown in table 4 below.

Table 4: Number of co-integrating relations by model

\begin{tabular}{cccccc} 
& Case 1 & Case 2 & Case 3 & Case 4 & Case 5 \\
\hline Data Trend: & None & None & Linear & Linear & Quadratic \\
\hline Test Type & No Intercept & Intercept & Intercept & Intercept & Intercept \\
& No Trend & No Trend & No Trend & Trend & Trend \\
Trace & 2 & 2 & 2 & 2 & 6 \\
Max-Eig & 2 & 1 & 1 & 2 & 2 \\
& & & & & \\
\hline \hline
\end{tabular}

*Critical values based on MacKinnon-Haug-Michelis (1999)

The results in Table 4 show that there is at least one co-integrating vector in the series based on both the Trace Tests and Maximum-Eigenvalues. We use case 3 from table 4 above, the null hypothesis that there are at most two cointegrating equations in the series is not rejected and thus conclude that there at are most two co-integrating equations at 5 percent significant level based on Trace Test. Similarly, based on the same assumption as above, the null hypothesis that there is at most one co-integrating equation at 5 percent significance level based on Maximum-Eigenvalues tests is not rejected. Since three outcomes were expected of the rank $\Pi$, and that there is neither a full rank nor a zero rank, it is 
concluded that the rank of $\Pi$ can be reduced and the sequence can then be analysed using the VEC model based on the first co-integrating equation which normalizes the Percap variable. The resultant co-integrating relation is shown in Table 5 (standard errors in parenthesis).

Table 5: Johansen (1991) Co-integrating Relationship

$\begin{array}{lccccc}\text { PERCAP } & \text { ST } & \text { GCF } & \text { BCP } & \text { M2 } & \text { MC } \\ 1.000000 & -2.078577 & -8.431017 & -1.083236 & 1.976308 & -0.122479 \\ & (1.24715) & (0.94275) & (0.12391) & (0.24423) & (0.01650)\end{array}$

Except for ST, all the coefficients are statistically significant at 5 percent. ST is significant at 10 percent. Of interest is the coefficient sign for short-term insurance firms (ST) which meets the priori-expectations by conforming to the model parameters. Expressed algebraically and including a constant term a VEC model equation is obtained as follows:

Percap $=4.06876+2.078577$ ST +8.43101GCF +1.08326BCP $-1.976308 M 2+0.12247$ MC (5)

Thus a unit change in ST leads to a change of 2 units in percap. The finance growth nexus is confirmed by the coefficient signs of BCP and MC in equation (5) above. The error correction from the VEC model vary significantly across the variables.

Table 6: Adjustment coefficients (standard error in parentheses)

$\begin{array}{cccccc}\mathbf{D}(\text { Percap) } & \mathrm{D}(\mathrm{ST}) & \mathrm{D}(\mathrm{GCF}) & \mathrm{D}(\mathrm{BCP}) & \mathrm{D}(\mathrm{M} 2) & \mathrm{D}(\mathrm{MC}) \\ -0.004225 & 0.012455^{\star *} & 0.171323^{*} & -0.017092 & 0.092006 & -5.884410^{*} \\ (0.02441) & (0.00675) & (0.02793) & (0.19811) & (0.15052) & (1.59871)\end{array}$

The Percap speed of adjustment is only 0.4 percent but is statistically insignificant. The short-term insurance variable adjusts downwards at a speed of 1.25 percent per quarter and is significant at 10 percent. From table 6 above, only ST, GCF and MC are statistically significant. The low speed of adjustment of ST means that the shocks in the variable take a longer period to adjust towards equilibrium. This suggests a weak adjustment in terms of both the size of the ST coefficient and the significance level.

The Granger causality results suggest that the short-term insurance industry does not significantly impact on the country's financial and economic development. This is further supported by the industry's weak speed of adjustment required to reach long-run equilibrium. In contrast to findings by Boon (2005), the results show a unidirectional causality suggesting that economic development can be used to predict future values of the short-term insurance industry. The relationship is significant at 5 percent. On the other hand, the short-term insurance industry can be used to predict GCF without any reverse feedback confirming findings by Boon (2005). Moreover ST has a unidirectional causality with MC (tstatistic $=1.7415$ ) which is however only significant at 10 percent. The rest of the Granger causality results contrast with findings from other studies such as Catalan et al (2000) and Outreville (1990). The impulse response functions are shown in below.

Figure 1: Impulse response functions

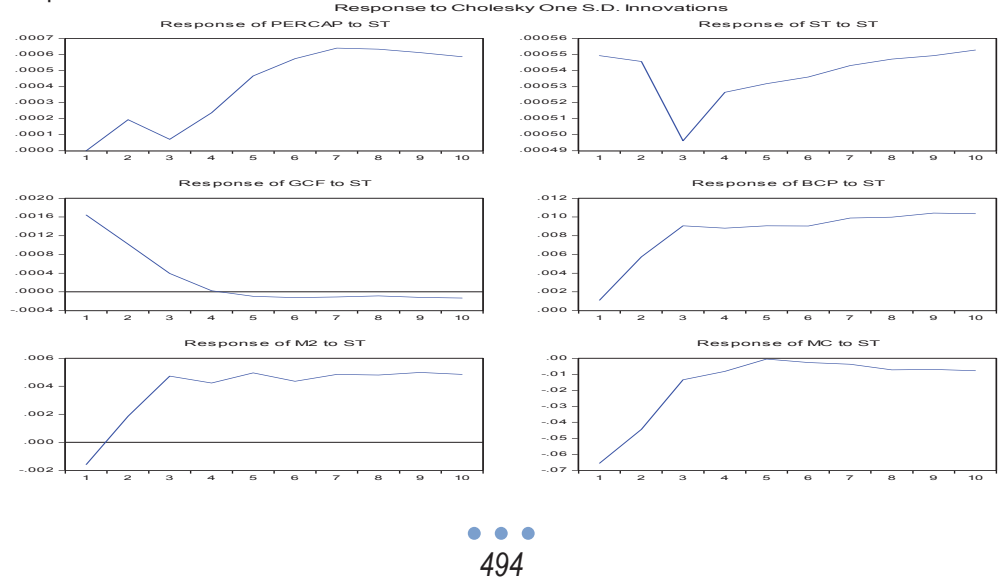




\section{Conclusion}

This study uses the Johansen (1991) co-integration tests, the VEC model and Granger causality tests to ascertain the influence of the short-term insurance industry on the finance-growth nexus in South Africa. Results show that a significant positive relationship exists between the short-term insurance assets and economic development. The results, however, fail to support the existing literature that the short-term insurance assets influence financial development as suggested by Boon (2005), Catalan et al (2000) and Outreville (1990). Furthermore, a unidirectional causality running from economic development to short-term insurance assets in South Africa is found in the study. This suggests that development of the short-term insurance industry is promoted by economic growth. This contradicts findings by Holsboer (1999), where a bidirectional relationship between the insurance industry and economic development was found to exist in Europe. Also a unidirectional causality running from the insurance industry to gross fixed capital formation is found to exist. This means that with the growth in the insurance industry more physical assets are created in the economy. This finding is supported in theory since capital formation leads to new assets being created in the economy. For economic agents to create these new assets, security needs to be guaranteed and in this case comes in the form of short-term insurance. Furthermore, a unidirectional causality from the short-term insurance industry to the stock market is found suggesting that the short-term insurance industry influences financial development through the stock market. This means that regardless of the variables used in the model, only economic development, stock market development and gross fixed capital may be used to explain changes in short-term insurance assets in South Africa. It can therefore be concluded that the development of the short-term insurance industry is necessary for the creation of new assets in the economy. Short-term insurers benefit from economic development and in turn propel gross capital formation in South Africa. No evidence suggesting that the short-term insurance industry promotes financial development through the banking sector and financial deepness was found in the study. However short-term insurance industry has a unidirectional causality with the stock market which is significant at 10 percent. These findings suggest that short-term insurance assets contribute to the finance-growth nexus through economic development, gross capital formation and stock market investment in South Africa. The results suggest that the Patrick (1966) demand-following proposition holds for South Africa.

\section{Implications and Recommendations}

The influence of the short-term insurance industry on economic growth through capital formation clearly articulates the importance of the industry in promoting confidence in the economy. The protection against unanticipated short-term adverse events increases the activities of economic agents in propelling economic development. With increased capital formation comes increased economic activity and economic development in the country. Thus evidence found in this study points to the increased need for development of the short-term insurance industry to ensure sustained economic growth. Therefore, developing countries should formulate policies that promote innovation and creativity in the short-term insurance industry as this would in turn propel economic development.

\section{References}

Asari, F.F.A.H., Muhamad, N.A., Ahmad, W., Latif, N.I.A., Addullah, N. and Jusoff, K. (2011). An analysis of non-performing loans, interest rate and inflation rate using Stata Software. World Applied Sciences Journal, Vol.12, pp.41-48

Beck, T., Levine, R. and Loayza, N. (2000). Finance and the sources of growth. Journal of Financial Economics, Vol. 58 No. 1-2, pp. 261-300.

Boon, T.K. (2005). Do commercial banks, stock market and insurance market promote economic growth? An analysis of the Singapore Economy. Working paper, Nanyang Technological University, Singapore.

Catalan, M., Impavido, G.Musalemu, A. (2000). Contractual savings or stock markets development: Which leads? World Bank Policy Research Paper 2421.

Committee on the Global Financial System (2007). Institutional investors, global savings and asset allocation. CGFS Papers No. 27, Bank of International Settlements, Switzerland, February 2007.

Davis, E. P. and Hu, Y. (2004). Is there a link between pension-fund assets and economic growth? - A cross-country study. Discussion Paper PI-0502, Pensions Institute, United Kingdom, December 2004.

Davis, E.P. (2003). Financial development, institutional investors and economic performance. Paper presented at the meeting of the British Association, Salford University, September 2003.

Fender, I. (2003). Institutional asset managers: industry trends, incentives and implications for market efficiency. BIS Quarterly Review, September. 
Goldsmith, R.W. (1969). Financial Structure and Development. New Haven, CT: Yale University Press

Gurley, J.G. and Shaw, E.S. (1955). Financial Aspects of Economic Development. The American Economic Review, Vol. 45, pp. 515538.

Gurley, J.G. and Shaw, E.S. (1956). Financial Intermediaries and the savings-investment process. Journal of Finance, Vol. 11, pp. $257-$ 276.

Gurley, J.G. and Shaw, E.S. (1960). Money in the Theory of Finance. Washington D.C: The Brookings Institution.

Gurley, J.G. and Shaw, E.S. (1967). Financial development and economic development. Economic Development and Cultural Change, Vol. 15 No. 3, pp. 257-268.

Haiss, P. and Sumegi, K. (2006). The relationship of insurance and economic growth - A theoretical and empirical analysis. Paper presented at the EcoMod Conference, Hong Kong, June 28-30, 2006.

Harichandra, K. and Thangavelu, S.M. (2004). Institutional investors, financial sector development and economic growth in OECD countries. Working paper No.0405, National University of Singapore, Singapore.

Holsboer, Jan H. (1999). Repositioning of the insurance industry in the financial sector and its economic role. The Geneva Papers on Risk and Insurance, Vol. 24 No.3, pp.243-290.

Hull, J.C. (2010). Risk Management and Financial Institutions. Massachusetts: Pearson Education.

Hurn, A.S. (1993). Seasonality, co-integration and error correction: An illustration using South African monetary data. Scottish Journal of Political Economy, Vol. 40 No.3, pp. 311-22.

Islam, M.A. and Osman, J.B. (2011). Development impact of non-bank financial intermediaries on economic growth in Malaysia: An empirical investigation. International Journal of Business and Social Science, Vol. 2 No.14, pp. 187 - 198.

Johansen, S. (1991). Estimation and hypothesis testing of cointegrating vectors in Gaussian Vector Autoregressive Models. Econometrica, Vol. 59, pp.1551-80.

Johansen, S. and Juselius, K. (1990). Maximum likelihood estimation and inference on co-integrated with applications to the demand for money. Oxford Bulletin of Economics and Statistics, Vol.52, pp. 169-210.

Kim, Y., Ho, I.S.M. and. Giles, M. S.T (2003). Developing institutional investors in People's Republic of China. The World Bank, September 2003.

King, R. and Levine, R. (1993). Finance and growth: Schumpeter might be right. Quarterly Journal of Economics, Vol. 108 No.3, pp. 717-38.

Levine, R. (1997). Financial development and economic growth: Views and agenda. Journal of Economic Literature, Vol. 35 No.2, pp. 688-726.

Levine, R. and Zervos, S. (1998). Stock markets, banks, and economic growth. American Review, Vol. 88 No.3, pp. 537-558.

Lim, C.C. and Haberman, S. (2003). Macroeconomic variables and the Demand for Life Insurance in Malaysia. Paper presented at the Oxmetrics Conference, Cass Business School, City University London, September 2003.

McGregor BFA Library (2012), McGregor BFA Research Domain, available at: http://research.mcgregorbfa.com .ezproxy.ukzn.ac.za:2048/Default.aspx (Accessed on various dates).

McKinnon, R. (1973). Money and Capital in Economic Development. Washington, DC: Brookings Institution

Outreville, J.F. (1996). Life insurance markets in developing countries. Journal of Risk and Insurance, Vol. 57 No.3, pp. 487-498.

Park, H., Borde, S.F. and Choi, Y. (2002). Determinants of insurance pervasiveness: A cross-national analysis. International Business Review, Vol. 11 No.1, pp. 79-96.

Patrick, H.T. (1966). Financial development and economic growth in underdeveloped countries. Journal of Economic Development and Cultural Change, Vol.14, pp. 174-189

South African Reserve Bank (SARB). Bank Supervision Department. Quarterly Bulletins, December 1995- December 2010.

South African Reserve Bank (SARB). Bank Supervision Department. Various Annual Reports.

Saunders, A. and Cornnet, M.M. (2008). Financial Institutions Management: A Risk Management Approach, Singapore: McGraw-Hill International Edition.

Schumpeter, J.A. (1912). The Theory of Economic Development. Leipzig: Dunker and Humblot, Translated by Redvers Opie, Cambridge, MA: Harvard University Press.

Solow, R.M. (1956). A contribution to the theory of economic growth. Quarterly Journal of Economic Growth, Vol. 70 No.1, pp.65-94

Solow, R.M. (1957). Technical change and the aggregate production function. Review of Economics and Statistics, Vol. 39, pp. 312-320.

Statistics South Africa: Quarterly publications.1995 -2010.

Ward, D. and Zurbruegg, R. (2000). Does insurance promote economic growth? Evidence from OECD countries. Journal of Risk and Insurance, Vol. 67 No.4, pp. 489-506. 